\title{
Psychoanalitical Outlook for Orwell's Coming Up for Air, Animal Farm and Nineteen Eighty-Four ${ }^{*}$
}

\section{Orwell'in Coming Up for Air, Animal Farm ve Nineteen Eighty-Four adlı Eserlerine Psiko-Analitik Bakış}

\author{
Zennure KÖSEMAN ${ }^{1}$ \\ İnönü Üniversitesi
}

\begin{abstract}
This article highlights a psychoanalytical approach while assessing how world wars cause mental and psychological disorders in human beings in respect to George Orwell's Coming up for Air (1939), Animal Farm (1945) and Nineteen Eighty-Four (1949). Rising global risks result in different forms of tension in financial, economic, and social respects. The atmosphere of perpetual crisis is influential on human psychology and personal values in worsening socio-economic circumstances. The role of psychoanalysis in literary criticism cannot be disregarded because of the rising global risks' influence on human beings. The chaos of World Wars is the reason for Orwell to portray an apocalyptic analysis in his fictional works. Orwell's aforementioned three novels in question here reveal a dark undertone of war and conflicts and manifest Orwell's tendency to portray individuals having anxiety, uncertainty, meaninglessness, alienation, and isolation in the modern world. Moreover, Orwell indirectly depicts that such psychological tensions end up rebellious activities of human beings in his novels.

Key Words: George Orwell, Global Risks, World Wars, Pre-Cold War Period, Human Psychology

Özet

$\mathrm{Bu}$ makalenin amacı, George Orwell'in romanlarında küresel tehditleri psikoanalitik eleştirel bağlamda yarattığı zihinsel ve psikolojik sorunları Coming up for Air (1939), Animal Farm (1945) ve Nineteen Eighty-Four (1949) adlı romanlarda değerlendirmek olacaktır. Artan küresel krizler, finansal, ekonomik, ve sosyal açıdan farklı gerilimlere sebep olmaktadır. Oluşan global gerilimlerin bozulan sosyo-ekonomik düzende insan psikolojisine ve değerlerine olumsuz yönde etki yaptığı görülmektedir. Global risklerin insanlar üzerindeki etkileri düşünüldüğünde, edebi eleştiride psikoanalizin rolü gözardı edilemez. Orwell'in eserlerinde apokaliptik değerlendirmeler yapılmasının sebebi gelişen dünya savaşlarıdır. Orwell'in belirtilen üç romanı, modern dünyada artan çekişmeler ve savaşlardan dolayı oluşan karamsar havayı ve çekişmeleri ortaya koymaktadır. Orwell eserlerinde, modern dünyada insanların yaşadğı endişe, belirsizlik, anlamsızlık, yabancılaşma, yalnızlaşma ve uzaklaşma gibi ruhsal bozuklukları sergilemektedir. Buna ek olarak, Orwell romanlarında dolaylı olarak, insanların yaşadığı

\footnotetext{
* This article is the extended version of the article presented in Turgut Özal International Conference on Economics and Politics-1: Global Crises and Economic Governance. 15-16 April, 2010, Inonu University, Malatya, Turkey.

${ }^{1}$ Yrd.Doç.Dr., İnönü Üniversitesi Fen Edebiyat Fakültesi Batı Dilleri ve Edebiyatları

Bölümü, e-mail: zennurekoseeman@yahoo.com.tr
} 
psikolojik gerilimlerden dolayı sisteme karşı tutum ve davranışlar sergilediğini anlatmaktadır.

Anahtar Kelimeler: George Orwell, Global Tehlikeler, Dünya Savaşları, Soğuk Savaş Öncesi Dönem, İnsan Psikolojisi

They were born after 1914 and are therefore incapable of happiness.

--Bertrand Russell

When individuals are dissatisfied with their situations, they become distressed suffering mental and emotional disorders. Bertrand Russell underlines the significance of this psychological emptiness in his famous wording while pointing at the incapability of happiness after 1914. The aim of this article is to analyze George Orwell's achievement in making a prophetic psychoanalytical evaluation of the ways in which human beings suffer the consequences of rising global risks in his literary masterpieces of Coming up for Air (1939), Animal Farm (1945) and Nineteen Eighty-Four (1949). As a prolific writer who produced many novels, articles, essays, and short stories such as "Why I Write?", "Looking Back on the Spanish Civil War", "Politics and the English Language", "Lear, Tolstoy, and the Fool", "Literature and Totalitarianism", "Shooting an Elephant" and "Reflection on Gandhi." George Orwell has a wide world perspective of awareness to interpret and parody world incidents in an ironic and critical point of view.

As a self-conscious social critic, George Orwell is one of the most prominent novelists in the English literary canon in the late 1940s through his social, economic, and political ideas and becomes one of the major literary milestones in the Cold War era and after. The fall of Communism in Eastern Europe and the dissolution of the Soviet Union between 1989 and 1991 changed the nature of the world in terms of the crisis lived before. In his literary works, Orwell deals with societies constructed on a denial of freedom and liberty (Evans 1987: 253). He tries to show how individuals become depressed psychologically due to inadequate living conditions. Orwell's fictional masterpieces should be reassessed in this context because they portray the consequences of sudden political and social changes of the pre- and post-Cold War period on human psychology and personal values. In his literary work, George Orwell satirically focuses on the problem of individuals who abuse power in a globalizing world.

Whereas many critics discuss Orwell in a Marxist context in order to reflect his satire on Russian Communism that terminate the revolutionary dynamics, this study will follow a psychoanalytical perspective (Frye 1987: 1011). Orwell implies that in individuals there is a search for freedom and liberty behind the oppressed living conditions. The outbreak of bloody wars, the increase of inequality and poverty in social and economic life, and the emergence of a new class of captains of industry encourage Orwell to criticisize how big changes influence individuals psychologically because of their growing awareness of the respective threats. Orwell becomes a socially sensitive writer 
of the financial, economic, and political matters. What Orwell pinpoints is that the real threat to England comes from Cosmopolitanism and globalization that are much more influential on people's inner lives (Parrinder 2006: 292). He focuses on how great events affect individuals psychologically and reflects his approach in his rebellious characters in his novels. In almost all of them, Orwell substantially portrays characters in an anxious state of escape and rebellion in their social, economic, and political living circumstances.

Derived from Sigmund Freud and Carl Gustav Jung, psychoanalytical criticism deals with the (interest on the) constitution of psychic structures in the text. Focusing on the subject studies of feminism, patriarchal psychic and cultural structures, psychoanalysis also centers on some other themes and motifs such as "desire and loss, delay and repetition or doubling, forms of prohibition, lack, sexual sublimation or repression". (Wolfreys 2006: 146-147). It reflects how human beings feel alienated and isolated in their living conditions in which they are dominated by repressive agents that force them to fall into a state of anxiety, meaninglessness, alienation, isolation and starngement. Psychoanalytical analysis offers a theory of mind and a theory of emotional depth (Jackson 2000: 1). Psychic criticism applies some of the techniques of psychoanalysis which intends to heal mental disorders that originate from fears and conflicts. George Orwell, focusing on mental disorders in sudden global changes, reflects how individuals do become distressed, and he portrays (their) affluence through(out) individual revolutionary activities because of being destructed by the war tensions. Orwell depicts global wars' becoming a problem for all humanity and is in a problem-solving attitude of ending wars.

Freud substantially works on the notion of three models of the psyche as the $i d$, the ego and the superego corresponding to the three levels of a person; on conscious and the unconscious, i.e., he interprets how traumatic events full of fears and conflicts occuring behind the control of individuals affect them subconsciously. Although Freud's ideals are mainly concerned with the aspects of sexuality, they also deal with instincts, fears and repression (Barry 2009: 9293). This article puts forward that Orwell's texts also depict how global threats are disastrous for human beings to become anxious of the continuity of their lives. They become rebellious individuals because of the fears and repression they experience in the historical and social circumstances:

Freud has a mechanistic and determinist model of mind as a whole. Though not of consciousness by itself. Consciousness, for Freud, is not self-determining. And the unconscious part of the mind does not wholly determine the conscious part. They interact. Our mental life is determined by the interplay of unconscious and conscious elements. The mind is a deterministic system (Jackson 2000: 34).

Thus, the implication is on how they correlate with each other and how matters influence conscious decisions. In Freud's terminology, real events or desires are transformed into dream images according to how people conceive them in their 
minds and how they reflect them in their feelings. In the condition of sleep, the force of repression is relaxed and the individuals have the freedom of dreams since there is no immediate likelihood of unconscious impulse of dangerous cases. This implies that dreams are the representation of the fulfillment of repressed wishes. Freud calls them the royal road to the unconscious where individuals also reflect their feelings throughout their attitudes and feelings (Wright 1984: 18; Jackson 2000: 62-63). People sometimes experience states of alienation, isolation, estrangement, and meaninglessness as given in Freud's explanation of the reasons for the emergence of dreams. In George Orwell's novels, most fictional characters rebel "against the system". And in the end they experience repression and depression in their environment. It is out of their control like the dreams Freud analyzes. Psychological disorders depend on how individuals interpret sudden historical and social changes in their living circumstances. Global events create influential controversial images on mental states and this signifies that psychoanalytical interpretations are mainly open to discussion in literary texts:

Freudian interpretation, then, has always been of considerable interest to literary criticism. The basic reason, again, is that the unconscious, like the poem, or novel, or play, cannot speak directly and explicitly but does so through images, symbols, emblems, and metaphors. Literature, too, is not involved in making direct explicit statements about life, but in showing and expressing experience through imagery, symbolism, metaphor and so on. . . . in consequence psychoanalytic interpretation of literature [is] often controversial (Barry 2009: 98).

Like the controversial images and symbols, the fictional characters in Orwell's novels express themselves by means of various revolutionary activities. Freud's follower, Carl Gustav Jung, considers the mind as a centre of conflicting forces that begins in childhood and follows a progressive course throughout the individual's life. If grown up in between the great world tensions, individuals, then, reflect their inner repressed worlds throughout their collective attitudes and behaviours. His human personality theory revolves around a self as the true centre of the psyche which forms the "totality of all psychic processes, conscious as well as unconscious." The unconscious state in which the individual experiences in the course of living circumstances is common to all men, it is "collective unconscious" (Wright 1984: 69-70). Orwell applies this Jungian outlook to his novels and makes the psychological disorders in the collective unconscious visible while demonstrating how his major fictional characters become rebellious in their living conditions because of being repressed as in the changing global events.

In Freud's theory of the unconscious and Jung's "collective unconscious," pessimistic imagery is significant to be dealt with, and Orwell's literary texts basically revolve around this (literary) outlook. This is the reason why it is necessary to study Orwell's novels in the context of psychoanalysis. The general 
historical and political context of England in the 1930s, a decade of political upheaval, was a period of conflicts that became influential on individual mental states. The Great War of 1914-1918 and the subsequent depression had influenced public confidence in the old ruling class. In Europe, two opposing political philosophies, Communism and Fascism, challenged the old representative governments and capitalist economies. The spread of Communist and Socialist movements in Europe had influenced many writers, such as George Orwell who criticizes his social environment in his works in order to obtain a classless peaceful society. The Spanish Civil War of 1936-1939 and World War II both were much greatly influenced by these two contradictory ideologies.

In such a political atmosphere, Orwell claims that radical political changes are necessary to end poverty and unemployment and to create equality and security. For Orwell, democratic socialism, workers' ownership of their production and a state-planned economy are essential to acquire a state of equality, wealth, and security (Meyers 1987: 1-2) His struggle to create counter activities against the socio-economic conflicts indicates his detest of the threats of wars. Orwell's rhetoric of political persuasion lies in his self questioning and his personal experiences. His writings are responses to the immediate issues of his age. In his 1946 essay, 'Why I Write', he expresses 'Every line of serious work that I have written since 1936 has been written, directly or indirectly, against totalitarianism and for democratic socialism ... .) (Filloy 1998: 47). This implies that he makes political writing as an art to deal with.

George Orwell takes into account the problem of being human in the modern world surrounded by the concurrent risks of world wars. Orwell's generation was the first which was influenced by the public and political realities of two world wars, of dictators, concentration camps, mass unemployment, and poverty. The existence of all those general risks was influential on Orwell's writing tendency to be concerned about the evils of class orientation, oppressive life styles, and poor living circumstances (Hynes 1971: 2-6). Orwell primarily focuses on the meaning of responsibility to indicate the reasons for the emergence of poverty and inequality in the modern world and reflects how individuals suffer from unequal living circumstances. He basically reveals a vein of nostalgia for leading a simple and happy life despite the current public and political problems, as, for instance he is in a pessimist mood of losing the innocence of a happy simple life in such a chaotic living circumstance because of world threats. While writing about the influence of world threats on human beings, Orwell emphasizes the necessity of pursuing simple and peaceful living on earth. He is in nostalgia for pursuing a calm life in his works centered on the idea of approaching apocalypse. Orwell has an intelligent appraisal of being a social critic of the social, political and economic circumstances.

Orwell approaches his novels in the sense of being a philosopher of human nature and human conditions. He discovers various ways to express political ideas and messages in his fictional works as in the fable of Animal Farm 
and dystopian satire of Nineteen Eighty-Four. In almost all his novels, Orwell depicts men who are in a state of alienation from social life because of the existence of various socio-economic and political issues. Global war risks of the 1930s and onwards are a means for expressing how men feel isolated and alienated in the middle of historical and social changes. He implies that such mental states are a result of psychoanalytical evaluations of great world events. Coming Up for Air, which was Orwell's first attempt to comment on the political situation in a novel published before World War II, alerts readers about rising external threats of war (Meyers 1991: 17). This implies that he warns all humanity about an approaching apocalyptic future full of technological dangers.

This novel reflects upon how sudden global changes influence human beings psychologically in their lives. George Bowling, the main character, is in a state of estrangement from old England of his childhood. His childhood memories form most of the arguments of the novel and play the role of displaying the contradictions existing between past and present. Thus, he is subconsciously influenced by his past memories and thinks about them in his own present situations. Derived from his crucial political experience in Spain and its consequences, Orwell depicts Bowling as a protagonist who has suffered a loss, disappointment and disenchantment (Williams 1991: 48-49). Thus, the main characters in his novels are the psychologically corrupted individuals who even lost their previous memoirs. They are basically in a nostalgia of their previous living environments. Moreover, they can be accepted as the mentally destructed individuals who are in lack of communitication with their surroundings because of their alienation and isolation. To illustrate, George Bowling's mental state reflects how he is repressed by his past and how he exposes it in his feelings. Written in the first person point of view, Orwell depicts Bowling as a man of forty-five who reveals his life while making a trip back to his boyhood home. In his profound, terrifying and wholly fascinating novel, Orwell indicates that Bowling is in a state of nostalgia hoping to go back and recapture his past glories. Coming Up for Air offers an apocalytic vision that destroys a nostalgic dream of a once lovely childhood. The main character, Bowling, is in a state of prophetic mood that predicts the end of the world and raises feelings that cause individuals to despair of their idealized childhood memories, as Orwell depicts a destructive future and a nostalgic past in his fictional narrative (Meyers 1987: 87). The emphasis is on the opposition existing between past and present in a frightful mess. He lives in his memories and this implies how Bowling is psychoanalytically under the influence of his feelings and emotions.

Coming Up for Air has two substantial themes dealing with the chaotic structure of the modern world. The first is a lament about the decay of pastoral Edwardian England and a complaint against the machine-civilization that has replaced it and the second is a warning against the approaching wars, the destructiveness of the battles, and the dangers looming behind the activities of different regimes active in Great Britain. This indicates that Orwell felt the fear 
of the approaching war which would cause the destruction of social values, feelings, and emotions. The figure of Bowling implies that he and his wife Hilda are the depressed and overweight stereotypes of the whole community. As a common man of his class and type, Bowling is coming up for air in order to rise up and refuse the cruelty and ugliness of war and the destructiveness of some modern developments such as the nuclear weapons (Meyers 1991: 89-92). He compensates his repressed feelings by his rebelliousness. This revolutionary activity is a sign for his reaction against the disastrous affects of the military equipments, i.e., he rebels against military authorities. His need for a simple and peaceful life is the reason for his riot, i.e. his attempt to come up for air. Bowling states in Coming Up For Air, "Stop firing that machine-gun! Stop chasing whatever you're chasing! Calm down, get your breath back, let a bit of peace seep into your bones." (Orwell 1984: 165). He implies that nuclear powers should be prevented in order to let all humanity live in peace in the world. Thus, Orwell primarily reflects the theme of the decay in the expanding modern world. George Orwell emphasizes that there should be independence of thought left alone by the repressive governments on earth. He expresses the emergence of global crisis of wars in a key passage in this fictional work:

War! I started thinking about it again. It's coming soon, that's certain. But who's afraid of war? That's to say, who's afraid of the bombs and the machine-guns? 'You are', you say. Yes, I am, and so's anybody who's ever seen them. But it isn't the war that matters, it's the after-war. . . . The coloured shirts, the barbed wire, the rubber truncheons. The secret cells where the electric light burns night and day, and the detectives watching you while you sleep. And the processions and the posters with enormous faces . . . . It's all going to happen. (1984: 149)

Rising public and political risks engage Bowling's mind and draw him into assessing a desperate construction of the modern world and a nightmare lying behind the wars. The existence of the anxiety concerning an apocalytic world emphasizes how Bowling evaluates himself to be enclosed by the dangerous powers of bombs and guns. Bowling expresses how all humanity is in a state of hopelessness, meaninglessness, and alienation because of war threats. Bowling comes up for an air of peace in the world in order to end all troubles in life.

Similarly in Animal Farm, George Orwell emphasizes a pessimistic outlook towards rising global risks on political grounds just before the beginning of the Cold War period. John Newsinger explains that Orwell's Animal Farm was mainly a book of a powerful assault on Russian Communism from a Trotskyist position in the comic form of an animal fable (1988: 116). Orwell again manifests how all human beings are affected by governmental rules and orders in this fictional work of fable. Orwell depicts a revolutionary generation being disturbed by socio-economic changes and political issues. His reference to world events manifests that George Orwell is a well-respected author in the genre of political journalism. Orwell manifests how individuals are disturbed because of their living environment and portrays them as being repressed, depressed and, thus, 
rebelious in this fictional work. How they are disturbed in their inner worlds is the main point Orwell deals with. The novel closes with the farm animals being crushed and the pigs and their neighbours becoming reconciled, signifying that they all resembled each other. Orwell expresses how the animals are disturbed by the social changes in Animal Farm as:

Twelve voices were shouting in anger, and they were all alike. No question, now, what had happened to the faces of the pigs. The creatures looked from pig to man, and from man to pig, and from pig to man again, but already it was impossible to say which was which (1988: 120).

Orwell's use of animals is a means of criticizing the changing living circumstances and events in the Stalin era before World War II. In Animal Farm, George Orwell has a humorous writing style in which the characters are considered animals to satirize Russian Regime of the time. These animals represent the people of the Soviet Union-and basically all people living on earth-and they are formed in a society which pursue the ideal of equality. It was written to "help bring about a revival of the socialist movement free from Communist influence" (Newsinger 1999: 117). Animal Farm addresses to the emergence of disorder in social life with regard to a decay of personal values such as rising indifference, ignorance, and greediness among human beings. The decay in the personal values is due to the rising materialistic globalizing of a world full of chaos. Orwell's Animal Farm is a satiric portrait of a dystopian society giving emphasis to the emergence of world threats like wars, terrorist attacks, and other disorders in the modern world (Meyers 1991: 103). Being disturbed by the oppressive cruel masters, the animals set up a revolutionary government in which each animal stands for a figure or a type. In George Orwell's Animal Farm, there is an allegorical farm which represents the communist regime in the world. Reading and writing pigs represent Bolshevik intellectuals who intend to dominate the vast Soviet bureaucracy. Napoleon is Stalin whereas Snowball is Trotsky and Squealer the propogandists of the regime (Meyers. 1991: 105). By emphasizing his satirical appoach upon dictatorship, Orwell informs his readers about a revolution that went wrong and became an anchor for the rising threats of global risks. Thus, individuals living in an oppressive despotic regime are called upon to stand up for their rights and to protect the world against the rising global crisis in this fictional work. In a psychoanalytical perspective, Orwell narrates how the animals-the stereotypes of individuals - become disturbed of their repressed living environment, and he depicts them as rebellious beings because of the tensions they have experienced in their unconscious psychological states.

Appealing to adolescents, the conventional short fable of Orwell's Animal Farm manifests how human nature becomes much more defensive against social and historical matters through holding revolutionary activities (Baldick 1996: 155). Orwell reflects several individuals' defensive standing in his novels and continues this reactive structure during the Cold War era. To illustrate, Orwell 
writes about the Seven Commandments of Animalism in which animals point out their rules of living in social order in Animal Farm: "All animals are equal, but some animals are more equal than others" (1988: 114). Giving insight into the Russian Revolution of 1917, this famous rule of Seven Commandments parodies the doomsday of a predicated change by the Bolsheviks. The dictum of Animalism, in fact, is a reference to the beginning of a better life by means of reflecting Clover's expressive thoughts of their past and present:

If she could have spoken her thoughts, it would have been to say that this was not what they had aimed at when they had set themselves years ago to work for the overthrow of the human race. These scenes of terror and slaughter were not what they had looked forward to on that night when old Major first stirred them to rebellion. If she herself had had any picture of the future, it had been of a society of animals set free from hunger and the whip, all equal, each working according to his capacity, the strong protecting the weak. (1988: 75-76)

In this quotation, Orwell emphasizes the necessity for the end of all graceless and evil activities of the great powers on earth. Clover's thoughts are a call for peace and security in the age of the global crisis. Because Clover and most of the other animals think that "they had come to a time when no one dared speak his mind, when fierce, growling dogs roamed everywhere, and when you had to watch your comrades torn to pieces after confessing to shocking crimes" (1988: 76). Thus, what they need is to express their thoughts, wishes and needs. By the Seven Commandments of Animalism, Orwell points out that the rules are supposed to maintain order for peace within Animal Farm. Here, Animalism is an allegorical mirror of the Soviet Union, particularly before and after the World Wars, as well as the evolution of the views of Russian revolutionaries and government's attitude towards practicing them. By portraying corrupt leadership as a flaw in revolution, this novel also displays how (potential) ignorance and indifference occurred during a revolution in the modern world. Although there is a political message most of the time here, it should not be forgotten that animals are reflected as psychologically depressed and oppressed from these political cases.

Orwell becomes much more critical about socio-economic and political issues in Nineteen Eighty-Four, and he shows how people become fearful and depressed of the great sudden changes in the world. This reflects how Orwell is concerned about the influence of the global changes on the inner lives of human beings. Orwell points out his aim behind writing this novel as "I do not believe that the kind of society I describe necessarily will arrive, but I believe (allowing of course for the fact that the book is a satire) that something resembling it could arrive" (Collected Letters IV 1968: 502). By being satirical, Orwell emphasizes the existence of fear behind the rising risk of perpetual wars that end up with poverty, death, and corruption in social order. This indicates that Orwell strikes a prophetic note on the future of the world in Nineteen 
Eighty-Four. Winston Smith, the main character in this masterpiece, is a lonely, guilty, and lustful person who is obssessed with the past. The name "Winston Smith," suggests that the name can stand for the real name Winston Churchill and Smith for any ordinary man. Such a political and common reference would represent how George Orwell evaluates his present living conditions in terms of political settings. Obsession of the previous events again mainfests a psychoanalytical assessment and signifies repression and fears in psychological orientation. Such global threats draw Winston Smith to be in a state of isolation, loneliness, and estrangement from himself, and the outer world because of considering meaninglessness in his living circumstances. Smith represents all humanity of that time by rendering visible their concurrent mental disorders.

Alistar Davies expounds that rising global risks originate from the expanding powers of Britain, Europe and America in the world in Nineteen Eighty-Four (2000: 104). Davies indicates that in Orwell's Nineteen Eighty-Four, Britain is seen as America's partner in its Cold War engagement in Europe (2000: 104). In Nineteen Eighty-Four, they are basically remarked as the great powers, Oceania, Eurasia, and Eastasia, each perpetually at war with one another. Such an interaction ends up the emergence of new public and political matters in the modern world. The emphasis is on how the Cold War happened to become a big threat in the global world. Orwell depicts the underlying tragedy behind the dangers of a globalizing world: "You are rotting away. . . . you are falling to pieces. What are you? A bag of filth. Now turn round and look into that mirror. Do you see that thing faces you? That is the last man. If you are human, that is humanity. Now put your clothes on again" (Orwell 2000: 246). Orwell implies that the loss of humanity generates from the rising global risks, becoming a threat to all human beings. In order to prevent this corruption, Orwell conveys that the individuals' rebellion against this horrible risk is inevitable and that individuals must do away with the isolation of their rebellion (Kubal 135). This signifies that individuals fall into a state of alienation and isolation because of the dangers of the modern world. The existence of such dangers is emphasized at the end of the novel in a satirical and warning thematic treatment when O'Brien calls Smith in an apocalyptic tone "the last man" in order to make visible the destruction of human spirit.

In a Letter in 1947, George Orwell writes to F. J. Warburg, the original English Publisher of Nineteen Eighty-Four, to express what the novel is mainly about:

This is a novel about the future - that is, it is in a sense a fantasy, but in the form of a naturalistic novel. That is what makes it a difficult job - of course as a book of anticipations it would be comparatively simple to write. (Collected Essays IV 1968: 329-30)

Animal Farm and Nineteen Eighty-Four are the two novels that depict the social, economic, and political circumstances of superpowers on earth. In Nineteen 
Eighty-Four, Orwell produces a naturalistic novel in which rising complex structures are pointed out in the era of global risks of economic, social, and political crisis. Besides being a novel of a pace-maker in the era of global dangers, Nineteen Eighty-Four underlines boundless despair and depressions in human psychology as a response to the changing social and political matters (Deutscher 39). Orwell projects a nightmare formed of displacement of humanity by politics that have caused hatred for the kind of public claims which desroy the possibilities and opportunities of individuals (Howe 44). In a psychoanalytical context, hatred is the outcome of chaos in politics and the public claims of the time. In this novel, Orwell provides an apocalyptic vision of the world in which there is a denial of human integrity and human values as a result of the traumatic events individuals do experience in life. He also emphasizes the existence of such problems through giving the predominance to following three themes in this masterpiece.

The first is the division of the world among three military superpowers possessing the new damaging atomic weapons in an era of perpetual war. In Nineteen Eighty Four, George Orwell reflects the consequences of absolute totalitarianism on human consciousness and the loss of integrity in life. The second is about different policies followed by each state, which resulted in some social classes developed beyond capitalism and socialism. And the third is the control of societies through repression and torture as well as "thought control" in totalitarian societies (Williams 1991: 99). While concentrating on the issue of global risks, George Orwell mainly considers western capitalism to be the reason for most problems on earth and the reason for the emergence of different political orientations. In Animal Farm, he remarks how a materialistic society based on money becomes corrupted via a dictum in Seven Commandments of Animalism: "No animal is ever to touch money" (12). In his warning about money in a prophetic way, Orwell manifests how it corrupts all human beings' moral values and their psychological states, and how it causes them to become materialists in the modern world. He demonstrates such an outlook in his review of Borkenau's The Communist International, in which he expresses how individuals turn out to be much more revolutionary by the rise of secular values in economic and social lives because they are repressed. Again, he gives proof of a psychoanalytical outlook by portraying individuals how they are disturbed by their living environment in their unconscious state:

If the problems of western capitalism are to be solved, it will have to be through a third alternative, a movement which is genuinely revolutionary, i.e. willing to make drastic changes and to use violence if necessary, but which does not lose touch, as Communism and Fascism have done, with the essential values of democracy. Such a thing is by no means unthinkable. The germs of such a movement exist in numerous countries, and they are capable of growing.(Collected Essays I 1968: 350) 
Orwell emphasizes how revolutionary activities become a counter activity in the existence of unequal circumstances due to poverty, unemployment, and injustice in their social circumstances. Orwell had three different forms of revolutionary activities as a response to contradictory issues current in social, economic, and political life. Raymond Williams indicates that in such a period of rising global risks before and after World War II, Orwell becomes a socialist in the thirties, a revolutionist in the forties, and a radical somewhere in between. In the 1930s, George Orwell had an idiosyncratic brand of socialism and produced his documentary work, The Road to Wigan Pier (Newsinger 1999: 21). Williams explains Orwell in different periods: an anti-imperialist of the early thirties, a revolutionary socialist and a radical essayist of the late thirties and forties. In The Lion and the Unicorn, George Orwell depicts his revolutionary patriotism, celebrating Englishness and socialism. Since there exists some contradictions in each period, Williams defines Orwell as a man who depicts various mental psychological states of isolation, disappointment, and estrangement behind his socialist talks (1991: 186). This indicates that Williams supports the argument of this article underlying how global problems becomes dangerous for the psychology of human beings.

To sum up, following psychoanalytical critical perspective, George Orwell's novels, essays, and documentaries strongly influence contemporary literature and thought because of conveying an evaluation of collapse in human psychology. Most of his literary works point out the existence of perpetual evils which cause hypocrisy and collusion in society. As a man of letters, he offers intellectual opportunities for reading due to his depicting public and historical events of his time in ironic and critical overtones. His literary works serve as documentary sources which record and interpret the politics and social changes. His novels make visible the corruption of social order that generates from war crisis and socio-economic problems. Orwell warns all humanity to be careful about the approaching apocalypse of great world wars since he believes that all humanity, as he emphasizes in his masterpieces, is living the advent of it. Thus, for Orwell, the threat of the imminent global crisis would account for the production of several literary works. He refers to the global crisis as a threat to all humanity and, thus, introduces the anxieties of globalization. The influences of global crisis on human psychological health are much more significant than the other outcomes in literary horizons in the first half of the twentieth century and also in later periods while other intellectuals substantially associate it with economic events and processes at the macro- and micro-level of human communities. Finally, since sudden global changes end up in mental distress, anxiety, socio-economic stress, and uncertainty, they are also held responsible for many individuals' requirement for an escape from their social living circumstances. Finally, such kind of mental disorders cause individuals to commit some crimes and perform some other rebellious activities as in Orwell's fictional works. 


\section{Works Cited}

Baldick, Chris. (1996). Criticism and Literary Theory: 1890 to the Present. London: Pearson Education.

Barry, Peter. (2009). Beginning Theory: An Introduction to Literary and Cultural Theory. III. Ed. Manchester: Manchester University Press.

Davies, Alistair and Alan Sinfield, (Eds.). (2000). British Culture of the Postwar; An Introduction to Literature and Society, 1945-1999. London: Routledge.

Deutscher, Isaac. (no date given). "1984-The Mysticism of Cruelty" Twentieth Century Interpretations of 1984: A Collection of Critical Essays. Samuel Hynes. (Ed.). New Jersey: Prentice-Hall.

Evans, Robert O. (1987). "The Nouvean Roman, Russian Dystopias, and Anthony Burgess." British Novelists since 1900. Ed., Jack I. Biles, New York: AMS Press. pp. 253-267.

Frye, Northrop. (1987). "Orwell and Marxism," George Orwell. Ed. Harold Bloom. New York: Chelsea House Publishers. pp. 9-13.

Filloy, Richard. (1998). "Orwell's Political Persuasion: A Rhetoric of Personality." New Casebooks: George Orwell. Hampshire: MacMillan.

Howe, Irving. (no date given). "1984: History as Nightmare." Twentieth Century Interpretations of 1984: A Collection of Critical Essays. Samuel Hynes. (Ed.). New Jersey: Prentice-Hall.

Hynes, Samuel. (1971). "Introduction." Twentieth Century Interpretations of 1984: A Collection of Critical Essays. Samuel Hynes. (Ed.). New Jersey: Prentice-Hall.

Jackson, Leonard. (2000). Literature, Psychoanalysis and the New Sciences of Mind. Essex: Pearson Education.

Kubal, David L. (1972). Outside the Whale: George Orwell's Art and Politics. Notre Dame: University of Notre Dame.

Meyers, Jeffrey. (1987). "Orwell's Apocalypse: Coming Up for Air," George Orwell. Ed. Harold Bloom. New York: Chelsea House Publishers.

Meyers, Valerie. (1991). Macmillan Modern Novelists: George Orwell. London: Macmillan Education.

Newsinger, John. (1999). Orwell's Politics. London: MacMillian Press.

Orwell, George. (1968). Collected Essays, Journalism and Letters of George Orwell. 4 Vols. Ed. Sonia Orwell and Ian Angus. London.

----. (1984). Coming Up for Air. (1939). Middlesex: Penguin Books.

----. (1988). Animal Farm. (1945). London: Penguin Books.

----. (2000). Nineteen Eighty-Four. (1949). London: Penguin Books. 
Parrinder, Patrick. (2006). Nation and Novel: The English Novel from its Origins to the Present Day. Oxford: Oxford University Press.

Williams, Raymond. (1991). Orwell. Ed. Frank Kermode. Fontana Modern Masters. London: Fontana Press.

Wolfreys, Julian. (2006). Key Concepts in Literary Theory. II Ed. Edinburgh: Edinburgh University Press.

Wright, Elizabeth. (1984). Psychoanalytic Criticism: Theory in Practice. London: Methuen. 